\title{
Historická sociologie mobility ve venkovském mikroregionu*
}

\author{
BOHUSLAV ŠALANDA**
}

Historical Sociology of Mobilities in the Rural Area

\begin{abstract}
The study analyzes the possibilities and limits of rural region motorization in Eastern Bohemia, since the beginnings up to 1989. Exploration of the topic also includes the problems of situated mobility. There have been the relations of the means of transport users (cars and motorcycles) to mobility followed, together with their experiences, ideas and opinions connected with this aspect of their lives. Attention is also paid to the advent of tractors, related to the socialist village collectivisation. In general, we are provided with a critical reflection of this specific area of technology, its pragmatics, social and symbolic functions in historical context. The knowledge has been mainly gaining through the author's field research.
\end{abstract}

Keywords: motorization; situated mobility; automobil; transport users; cars, motorcycles, tractors

DOI: $10.14712 / 23363525.2019 .8$

\section{Úvod}

Dějiny samy o sobě jsou velmi vrstevnaté, možná i z tohoto důvodu existuje značná mezera v zachycení (auto)mobility obecně v rámci urbánních dějin; nejen to - tato neúplnost se týká i dějin venkova, a to jak na makro- , tak mikroškále. Téma lze pojednat historiograficky s přesahem do hospodářských a sociálních dějin, ale rovněž historicko-sociologicky, popř́padě etnograficky. Celkově vzato běží mimo jiné také o studium materiální kultury (věcí, reziduí apod.).

Ve venkovském mikroregionu na Poličsku, respektive Litomyšlsku (hlavně v Širokém Dole, Lubné, Zrnětíně, Dolním Újezdě aj.) je sledován obraz motorismu ze širšího hledis$\mathrm{ka}$, a to nejen s ohledem na vývoj zájmu uživatelů o jednotlivé značky automobilů a motocyklů. Ve zvoleném mikroregionu se lze zabývat rovněž nástupem traktorů v souvislosti s násilnou kolektivizací venkova.

Obecně budou analyzovány možnosti a limity motorizace v dané oblasti. Můžeme s nadsázkou konstatovat, že se jedná o jistý druh „lidového autosalónu“, který byl vymezován (omezován) tehdejšími možnostmi, především dostupnou nabídkou tuzemských a šiřeji východoevropských automobilových značek. Součástí bádání se dále př̌ednostně stává zájem o vztahy uživatelů $\mathrm{k}$ (auto)mobilitě, o jejich zkušenosti, představy a názory. Jinak řečeno, do hry tu vstupuje situovaný automobilismus.

Vydáno za finanční podpory Ministerstva kultury ČR v rámci projektu NAKI II České století motorismu (DG18P02OVV051), který v letech 2018-2021 realizují Fakulta humanitních studií Univerzity Karlovy, Národní technické muzeum a Technické muzeum v Brně.

** Doc. PhDr. Bohuslav Šalanda, CSc., Pracoviště historické sociologie, Fakulta humanitních studií, Univerzita Karlova, U Kř́že 8, 15800 Praha 5. E-mail: bohuslav.salanda@fhs.cuni.cz. 
Prozatím není zcela jasno, jaký teoretický „background“ právě v případě venkovské mobility bude možno uplatnit. Určitě se tato oblast včleňuje i do linie zkoumání materiální kultury. Klasická etnologie nebo etnografie přitom do výzkumů venkovských populací nasazení strojů tohoto typu nezahrnula. V př́padě uvedených mobilních prostředků dochází průběžně $\mathrm{k}$ jejich přejímání a adaptaci na venkovské poměry; jde o recipování a následné zasazení daných jevư do specifického rámce. Je nutno počítat rovněž se způsoby získávání automobilů, motocyklů, traktorů a dalších strojů, přičemž stranou se postupně ocitá původně dominantní koňská (popř́padě kravská) síla.

Rozsáhlý projekt ke studiu motorismu již vypracovali Jan Štemberk a Ivan Jakubec. Oba si byli dobře vědomi toho, že této oblasti dosud nebyla věnována soustavná pozornost. Jmenovitě Ivan Jakubec doslova uvedl: „Je však až s podivem, že dosud v české historické literatuře bylo motorismu a jeho širokým souvislostem věnováno jen tak málo prostoru a řada témat nepřilákala dosud pozornost vůbec. Cílem tohoto textu je nastínit současný stav zpracování motorismu v české historiografii a současně poukázat na nezpracovaná místa a formulovat otázky, kterým by se měl další výzkum při hledání odpovědí vydat“ [Jakubec 2018: 128].

\section{Předpoklady výzkumu mobility}

V současné době zaznamenávají značnou oblibu práce, jež se z hlediska svého záběru pohybují na makroškále a vypovídají o stavu světa. Neustálou aktuálnost vykazují rovněž publikace Alvina a Heidi Tofflerových [2001] týkající se nástupu nových systémů tvorby bohatství „třetí vlny“. Podle těchto autorů se mění způsob, jak lidé zacházejí s časem, prostorem, znalostmi a mnoha dalšími hloubkovými skutečnostmi. Přitom se zároveň proměňuje povaha práce, struktura rodinného života, druhy médií, jakož i sociální, institucionální, kulturní a politické struktury. Pokročilé znalosti se stávají důležitějšími než staré „výrobní faktory“, jako jsou především půda, práce a kapitál. Tyto a jim podobné trendy lze ovšem prokázat jen důkladnými výzkumy, zaměřenými mimo jiné na lokální společenství.

V této souvislosti konstatujme, že zde představené terénní výzkumy lokálních společenství jsou dlouhodobě zaměřeny etnosociologicky a podávají svého druhu mikrosociologii, respektive mikrohistorii venkovské části české populace. Výzkum se věnuje konkrétním sociokulturním fenoménům na lokální úrovni, přičemž mimo jiné detailně zachycuje různé aspekty expresivního chování. Zjištěná data pak mohou sloužit taktéž pro komparaci diverzity sociálního života a subkulturních variací v moderním českém etniku. Jedná se tak vlastně o studium kulturních variací, regionálních historických a ekonomických sil a trendů [viz např́iklad Kotak 2000: 55].

Pro postižení sociální situace jsou využívány poznatky „z první ruky“, tedy získané vlastním pozorováním (z větší části participativním) a rozhovory s respondenty či pamětníky. Pro takovouto „polní práci“ (fieldwork) se hodí vymezené lokality přijatelné velikosti, zhruba do 400-500 obyvatel, jedině tak může být totiž zajištěna určitá přehlednost terénu. V současné době informace získáváme především ve veřejných prostorech, málokdy se lze dostat př́mo do domácnosti. Pokud nedorazí osobní pozvání, o své vlastní vůli neklepeme na dveře domu.

Následující úvahy se budou opírat o svědectví (ústní podání) několika místních, „lidových historiků“, kteří dovedou v kostce vykládat o mobilitě, přičemž své rozvahy a doklady 
doprovázejí poměrně přesnými letopočty. Určitě disponují podrobnými znalostmi. Dále jsou schopni přesně datovat konkrétní dopravní prostředky: kdy se dané stroje dostaly do určitých lokalit. Detailně přitom popisují využití těchto prostředků apod. Bohužel nikdo z nich si nepíše poznámky, nebo přímo kroniku; informace uchovávají jen ve své paměti. Velmi vhod by tak přišly zmíněné kroniky o minulých technických vymoženostech.

Dosavadní výzkumná práce se dostala až na hranici soukromé sféry obyvatel příslušných lokalit. Všechny důležité informace zůstaly odkryty, a to včetně jmen respondentů, čísla popisného domu jejich bydliště apod. V žádném př́ípadě tudíž nejde o anonymní dějiny. V této souvislosti se tím pádem naplno vynořují otázky etiky výzkumu. Nelze přece lidem lézt až do kredence $\mathrm{v}$ kuchyni nebo s nimi podrobně probírat zcela privátní záležitosti ...

Pro úplnost uved'me, že se v ohnisku autorova přednostního badatelského zájmu objevuje dlouhodobě sledovaná lokalita ve východních Čechách - Široký Důl vzdálený 6 km od Poličky a 16 km od Litomyšle. Jde o historicky opakovaně zkoumanou vesnicí, která byla již od začátku 20. století mnohokrát v centru badatelského zájmu různého rozsahu a zaměření. V letech 2003-2005 zde probíhal poměrně intenzivní výzkum také za účasti tehdejších studentů nově založeného oboru sociální antropologie na Univerzitě Pardubice. Samozřejmě nezůstáváme badatelsky omezeni pouze na tuto lokalitu. Sondážní výzkum se provádí i v dalších obcích, přibližně v okruhu 10-15 kilometrů od referenčního Širokého Dolu.

Vývoj počtu obyvatel Širokého Dolu vypadá v číslech následujícím způsobem: 1861 (654 obyvatel), 1900 (585), 1921 (570), 1950 (394), 1970 (345), 1991 (358), 2018 (420). Podle údajů z roku 2017 žije ve vedlejší vesnici Lubná 987 obyvatel, v Zrnětíně 80 a ve vzdálenějším Dolním Újezdě 1982 lidí.

Do stručné charakteristiky sledovaného Širokého Dolu patří ve vývojové perspektivě velké změny civilizační, ekonomické, sociální a kulturní povahy. Toto „sídlo dějin“ se ve svém historickém rozvoji posunulo od tradičního a zemědělského sídelního typu k vesnici industriální a rekreační. Právě místní podnikatel Karel Flídr využil pracovitosti, zručnosti a skromnosti nejen lidí z obce k vytvoření továrny, jež v mnohém navazuje na automobilový průmysl (např́klad kovové opěrky k sedadlům a plasty pro různé využití). Dále se tu vyrábějí hasičské hadice a šroubení. Početně zhruba čtvrtina z dvou set zaměstnanců se přitom rekrutuje přímo z místa. Zmíněný podnikatel nejen že tímto způsobem vytvárí takřka plnou zaměstnanost, nýbrž i všemožně podporuje zdejší dobrovolné hasiče v jejich technických záležitostech a ve sportovním vyžití.

O Širokém Dole byla vydána monografie podávající pokud možno celkový pohled na shora naznačené trendy v uplynulém století [Šalanda 2008]. V získávání prvotního materiálu autor nadále pokračuje ve snaze učinit ze zvolené lokality trvale zkoumané teritorum. $Z$ velké části to však nezáleží jen na badatelově usilování, hlavním momentem zůstává ochota místních obyvatel dále „snášet“ jeho přítomnost ve svém sídle, přičemž patrně mnoho respondentů má dojem, že vlastně již všechno bylo vyzkoumáno, že již oni sami všechno sdělili. Protože plánujeme původní monografii rozšírit a doplnit o další poznatky, bude to vyžadovat další revitalizaci výzkumu. Takže v Širokém Dole i jinde je třeba nadále zůstat činný v oblasti veřejných aktivit, expresivních, sociokulturních konfigurací. Podstatně se rozšiřuje bádání v provozních záležitostech, stručně řečeno v mobilitě. 


\section{Počátky moderní mobility na vesnici}

Počátky moderní mobility (zatím bez motorizace) jsou na vesnici spojeny s jízdními koly. Jedná se o období těsně po roce 1900, respektive těsně před Velkou válkou. (V té době sice už nastupují automobily, jsou však vyráběny v malém počtu, cenově dostupné jen omezené elitě.) Jízdní kola vybavená nosičem se rychle stala univerzálním dopravním prostředkem $\mathrm{v}$ domácnosti a také $\mathrm{v}$ hospodářství. Byly na nich dopravovány přebytky na trh nebo na výměnu (nejen plodiny, ale i drůbež a drobné zvířectvo).

Tak např́iklad prodej kol na Pardubicku před Velkou válkou mohl probíhat tak, že obchodník v rodinném železářství a klempířství je rozvážel po dvou do širokého okolí. Přitom na jednom kole jel a druhé vezl vedle sebe; zpět se pak vracel pěšky. Takový obchodník těžil ze zájmu hospodářo̊ na vesnicích. Možná, že zpočátku se v rovinatých terénech kola prodávala a šírila o něco lépe než tam, kde bylo hodně kopců.

Automobilový průmysl spolu s výrobou motocyklů spíše sporadicky zásoboval svými výrobky mezi dvěma světovými válkami i venkov. První exkurz zachycuje motocykl „těžší kubatury“ konstruktéra Jaroslava Františka Kocha (1893-1983), který přišel se strojem typu BD 500; později byl vyráběný pod značkou Praga. Motocykl značky „Bed’ar“ měl motor 499 ccm s výkonem 15 koňských sil a mohl být opatřen přivěsným vozíkem („sajdkou“) i s užitkovou nástavbou. (Disponovala jím československá armáda a četnictvo.) Již před rokem 1939 tento stroj vlastnil významný hospodář v Širokém Dole Karel Telecký (1910-1983).

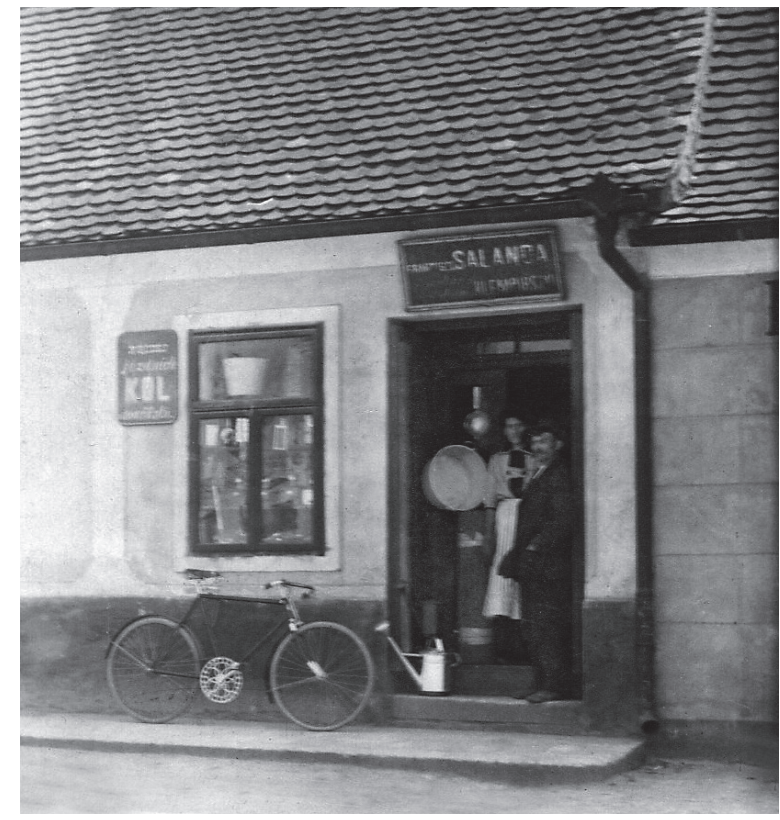

Obrázek 1: Prodej kol na Pardubicku kolem roku 1913. Foto: Archiv autora 


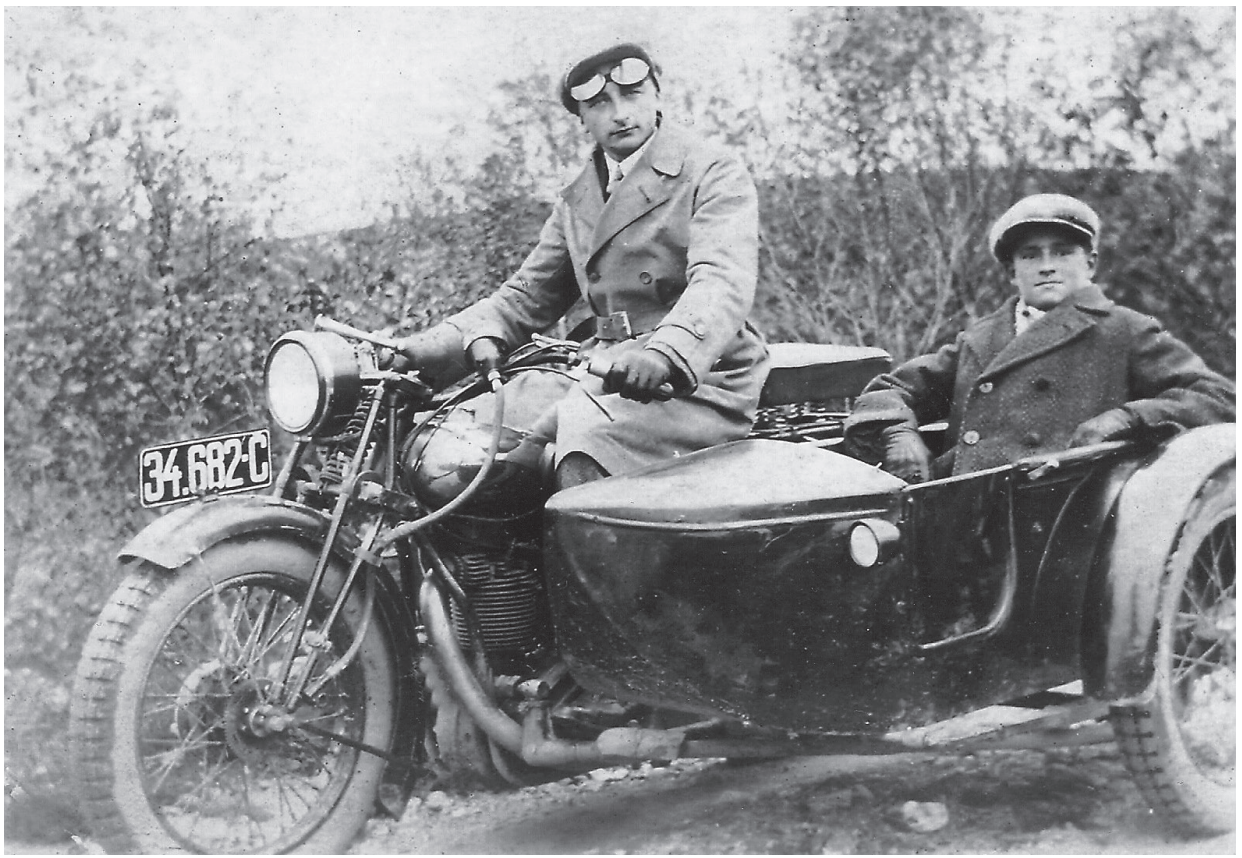

Obrázek 2: Motocykl značky BD 500 („Bed’ar“), 1939. Foto: Archiv autora

V roce 1929 začala výroba motocyklů Jawa, od roku 1945 modelu Jawa 11 (lidově zvaného „pérák“). Nás především zajímá v návaznosti na „pérák“ takzvaná „kývačka“, žádaný stroj mladých mužů na vesnici. V té době se jednalo o prrímo ikonický motocykl. Dále přichází malý motocykl Jawa 50 Pionýr, který se rovněž objevoval ve výbavě některých domácností. Subtilní moped Stadion plnil funkci „přibližovadla“ na nevelké vzdálenosti. Někdo si pořídil i elegantní moped Jawa M-207 Babetta, vyráběný v Považské Bystrici v letech 1973-1983.

Druhý exkurz se týká malého automobilu značky Trabant, který měl jak známo původ v Německé demokratické republice (DDR). Tento vůz s karosérií z duroplastu provází řada ambivalencí: na jedné straně auto cenově nejdostupnější, vůbec nejlevnější, na druhé straně vybavené hlučným dvoudobým motorem se vzduchovým chlazením. (Ovšem zpočátku byly dvoutaktními motory vybaveny i mnohé jiné automobily, jako např́klad švédský Saab, italský Fiat 500, německý Volkswagen a další.) Jak ještě ukážeme, jednalo se ve zkoumaných podmínkách o velmi praktický vůz, i když ne zcela pohodlný. Zároveň byl nenáročný na údržbu. Především verze kombi sloužila k dopravě zemědělských produktů, mlád’at hospodářských zvířat, králíků apod. Rozhodně to nebylo pouze v jednotlivých případech. Ve střediskových obcích, například v Dolním Újezdě, se v 70. a 80. letech používal Trabant jako služební vozidlo, byl proto vybaven telefonem-vysílačkou pro organizaci a koordinaci zemědělské výroby (kupř́ikladu žňových prací). Jen v dané obci jezdilo kolem dvaceti takto uzpůsobených vozidel. Jak již bylo řečeno, prim tu hrála i cenová dostupnost tohoto automobilu. 


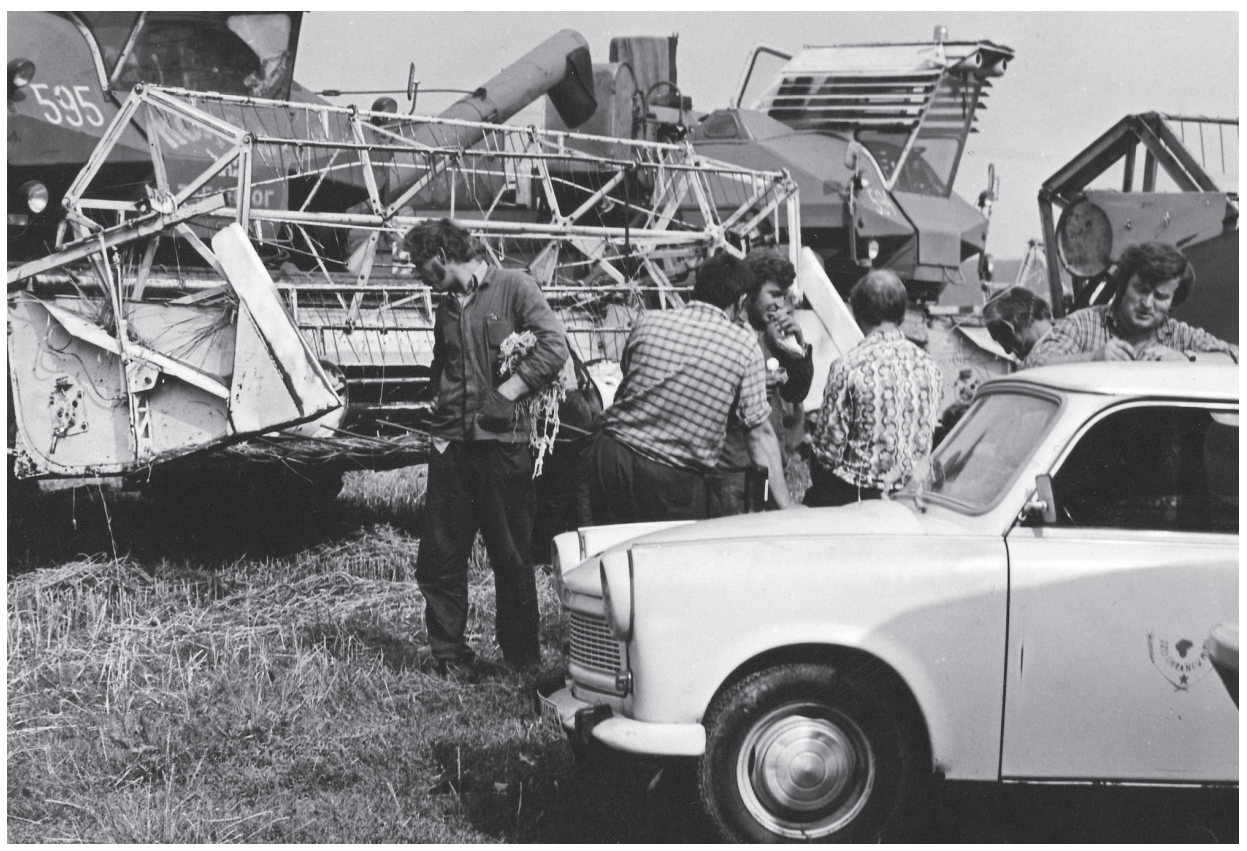

Obrázek 3: Trabant jako služební vozidlo, 80. léta 20. století. Foto: Archiv autora

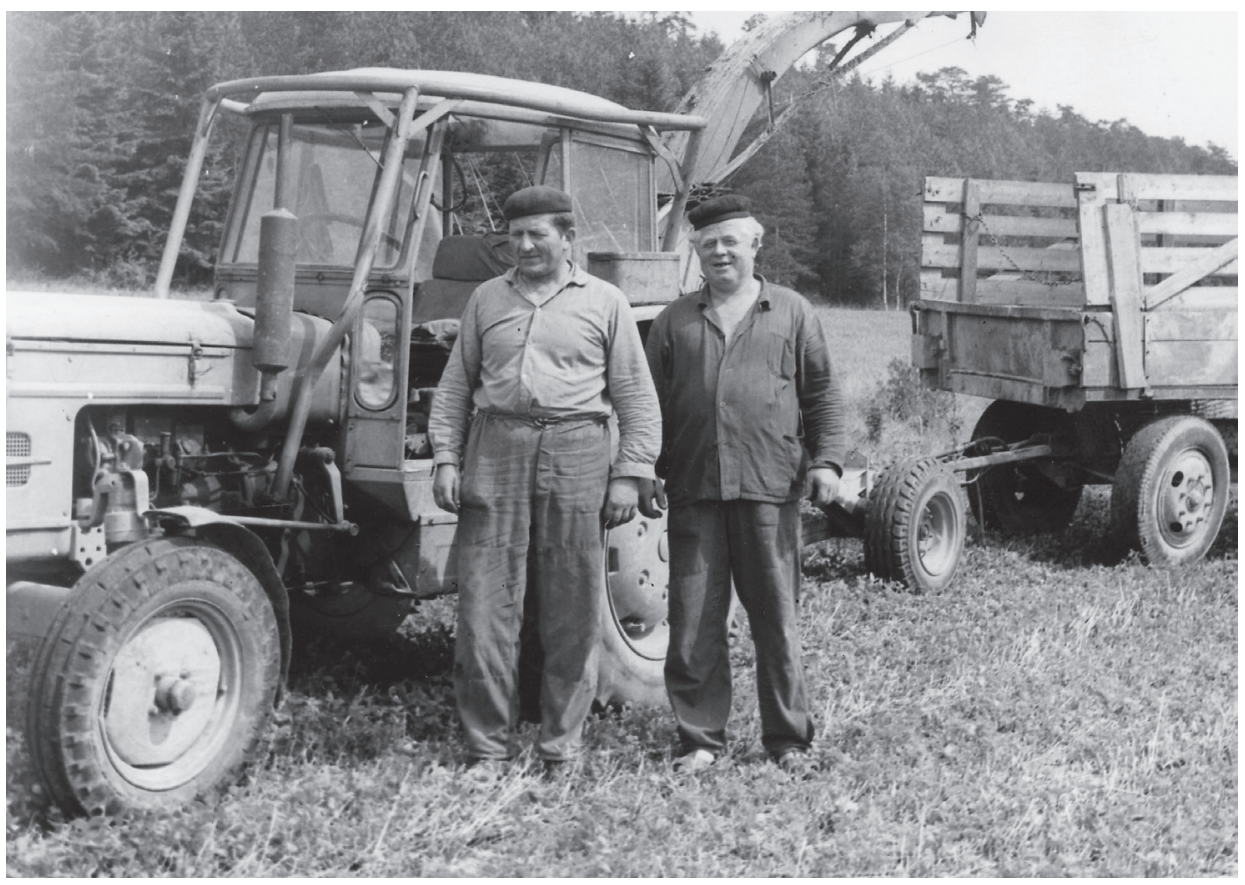

Obrázek 4: Traktor Zetor Major. Foto: Zdeněk Kočík 1973 
Dovoz Trabantů 600 do Československa začal roku 1963, přičemž o dva roky později k tomuto typu přibyl nový Trabant 601 a v roce 1965 se objevila verze kombi, Trabant 601 Universal. Hodí se dodat, že počet Trabantů u nás kulminoval ve druhé polovině 70 . let.

Mezi oblíbené značky automobilů „východního bloku“ v našich poměrech patřily Moskviče [viz např́iklad Jan Tuček 2009]. Avšak ve zkoumaném mikroregionu se ve velkém počtu nevyskytovaly, spíše jen sporadicky.

Kolektivizace zemědělského hospodaření byla v této oblasti v plném proudu ve druhé polovině 50. let. Předtím se zde vyskytovala např́iklad strojní družstva disponující třeba traktorem, který byl půjčován mezi členy podle výše vkladů. Byl to hlavně „jednoduchý“ Zetor 25 bez kabiny a později i s ní. Tento model stál doslova u zrodu JZD, byl totiž jako jeden z prvních převeden do kolektivního vlastnictví. Tvořil na počátku násilné kolektivizace prvotní výbavu sledovaných obcí na Poličsku. Z dalších „úsporných“ traktorů uved’me značku Zetor Major, vyráběnou od 60. let.

Éru zemědělské velkovýroby potom zahájil na začátku 70. let traktor Zetor Crystal, který poprvé sjel z výrobních pásů roku 1969. Kabinu poměrně pohodlného stroje tvořila odsazená kapota s obdélníkovým čelním sklem. V této době se objevují ve velké míře také sklizňové kombajny, které byly i s posádkou zapůjčovány sousedním nebo vzdáleným zemědělským družstvům. Shora naznačenou neúplnou mozaiku mobilních aktivit však bude třeba doplnit a rozšírit v dalších studiích.

\section{Odbočka k současnému sběratelství mobilních prostředků}

Ve zkoumaných souvislostech vystupují do popředí taktéž výrazové komunikační formy: ceremoniály, rituály a performance. Někdy se při takových příležitostech dokonce záměrně určité aktivity vymýšlejí a v jejich čele vždy stojí schopný iniciátor a organizátor.

Příkladem se může stát vymyšlení jedné tradice konkrétním aktérem, v tomto případě bývalým starostou obce Široký Důl Václavem Vopařilem (nar. 1959). V podstatě běží o volnočasovou aktivitu přimykající se ke sběratelství materiálních (technických) artefaktů. Václav Vopařil zorganizoval sraz historických motorových vozidel, tzv. veteránů. Na hasičském hřišti s travnatým povrchem bylo 7 . července 2012 k vidění kolem 300 kusů motocyklů a automobilů. Původně se počítalo se 40 účastníky, ale přijelo jich o stovku více. Právě tento v pořadí druhý sraz veteránů předčil všechna očekávání. Pozvánky pravidelně slibují od 9 do 11 hodin prezentaci, dále od 12 do 14 hodin obvykle probíhá „kochaci“ vyjížd'ka po okolí, a konečně pak po dojezdu je naplánována živá hudba a bohatá tombola. Zároveň se podává občerstvení a prodává př́slušná technická literatura.

Setkání historických dopravních prostředků, hlavně automobilů a motocyklů, se odehrávají podle stejného scénáře, celodenní program se děje ve stylu „retro“, kam spadá i dobové oblečení. Tak např́iklad při 8. srazu veteránů, konaném 7. července 2018, přibyla do programu od 19 hodin retro diskotéka. Zkrátka a dobře - jedno velké retro.

Za pozornost stojí, že první a nejlákavější cenu v tombole tehdy představoval motocykl značky Jawa 250, lidově zvaný „kývačka“. Tato motorka sériově vyráběná v letech 1954-1962 byla jako přibližovací prostředek snem mnoha mladých mužů a dodnes se na venkově honosí statutem oblíbeného nostalgického exempláře. Mezi shromážděnými veterány byl vždy zastoupen $\mathrm{v}$ dosti velkém počtu, navíc loni byl ještě speciálně vystaven a obklopen rozsvícenými svíčkami, protože se na něm při havárii zabil mladý člověk. Pro 
venkovskou část populace se stala tato značka motocyklu stejně významnou jako pro městské obyvatelstvo skútr. Připomeňme v tomto kontextu alespoň letmo skútr VESPA, který se v Itálii od začátku 50. let stal lidovým dopravním prostředkem. V Čechách dodnes existují speciální kluby této značky.

Na tomto poli se nabízí aplikace širšího pojetí mytologie, respektive „mýtu dnes“ francouzského sémiologa Rolanda Barthese [2004], jenž upozornil mimo jiné na to, že artefakty mohou získat jistou symboliku či znakovou funkci. Určité značky dopravních prostředků se často stávají ikonami, přičemž se také repasují nebo v jejich nitru probíhá tzv. tuning.

Shora uvedeným způsobem se také projevuje vztah k minulosti, a to „neživé, ve smyslu nekonfliktní, nekontroverzní, neideologické. Nejde o živou minulost, která dosud zůstává ve společenské paměti např́klad v podobě vzpomínek na násilnou kolektivizaci venkova, vyvlastňování, vyhánění a dalších příkoří. V tomto případě se mnohem více na jedné straně neformálně ukazuje vztah k dějinám techniky, na straně druhé rukodělná zručnost a schopnost improvizace.

Do sémantické hry může taktéž vstoupit oblíbená „bricolage“ jako kutilství nebo nepř́má cesta, jinak řečeno strukturální improvizace, metaforicky vyjádřeno „flikování“ či „záplatování, jakož i přesouvání referenčních rámců. Lze tu pak uplatnit „těžký metodologický kalibr", totiž myšlenky francouzského sociálního antropologa Clauda Lévi-Strausse, podle něhož kutil vyrábí nebo vylepšuje věci nikoli z nového materiálu, nýbrž naopak ze starých věcí. Ovšem hranice mezi kutilstvím a „inženýringem“ mưže být oboustranně dosti prostupná, o čemž svědčí právě v Širokém Dole předváděné technické kusy.

Každopádně se díky podobným aktivitám stará technika nestává odpadem, nekončí v železném šrotu, ale je svědomitě opravována a udržována v provozu. Chybějící nebo vadné součástky jsou vyhledávány pomocí internetových a tištěných inzerátů, popřípadě osobně získávány na specializovaných burzách.

Při širokodolských srazech technických veteránů byl také opakovaně páskou ohraničen prostor, který vyplnil Jan Procházka (nar. 1943) z obce Kamenec u Poličky malou ukázkou ze své sbírky tzv. stabilních motorů. Jedná se o jednotky se spalovacím motorem zážehovým nebo vznětovým, poháněným petrolejem, benzolem a benzínem. Tyto většinou jednoválcové motory pracující na čtyřtaktním principu doplňoval setrvačník kvůli zajištění pravidelného chodu. Jak název napovídá, využívaly se pro pohon stabilních zařízení, jako např́klad mlátiček, vodních čerpadel, pil na dřevo aj. Největší rozkvět zaznamenaly mezi dvěma válkami, kdy došlo k podstatné (technické a strojové) inovaci větších zemědělských usedlostí. Sběratel Jan Procházka pokračování této éry zažil jako dítě v rodině zemědělce, který až do násilné kolektivizace hospodařil na rozloze 12 ha polí, luk a lesa v osadě Jelínek na dohled zmíněné obce Kamenec. Svou monotematickou sbírku asi 50 strojů roku 2005 umístil do menší stavby pro ten účel speciálně zbudované. Lze proto bez nadsázky hovořit o domácím technickém muzeu, které nepravidelné a př́ležitostné návštěvy registruje do speciálního sešitu. Ve své podstatě ovšem takovéto sběratelství není motivováno snahou proměnit sbírku v nějakou lukrativní záležitost. Jan Procházka naopak odsuzuje podobné sběratele, kteří svou volnočasovou aktivitu směrují také k vlastnímu finančnímu obohacení. Nutno ještě dodat, že Jan Procházka v této sféře volnočasových aktivit vystupuje jako samouk, i když roku 1964 absolvoval proslulou střední zemědělskou školu v Litomyšli. Do roku 1982 pracoval v zemědělském družstvu v Kamenci a odtud se přesunul do technických služeb v Poličce. Můžeme tedy říci, že měl k technice vždycky blízko. 
Při podobných př́ležitostech se nabízejí různé otázky, z nichž na prvním místě se nejspíše objeví ta nejprostší: proč to vůbec tito lidé dělají? Zároveň se patrně shodneme na tom, že jde o technické záležitosti, jimiž se ve volném čase zaobírají především (téměř výhradně) muži. Ženy přitom nejsou z účasti vyloučeny, připadá jim však povětšinou role pouhého doprovodu.

Jednou z možných odpovědí na výše položenou otázku je pojem prestiže, jenž má sám několik dalších vrstev a významů, a to nejen ve vztahu k profesi nebo povolání. $\mathrm{V}$ tomto př́ípadě se jedná o úctu, respekt, reputaci, obdiv, pověst jedince nebo sociální skupiny, vše obvykle přesahující vlastní lokalitu. Nutno navíc zdůraznit, že tuto aktivitu nelze zahrnout do sféry nevážného, nýbrž je třeba ji posuzovat coby záležitost skutečně vážnou, podtrhující mimořádné vlastnosti a schopnosti každého sběratele. Tak například samotný organizátor srazu veteránů Václav Vopařil posiluje tímto způsobem nejen svou osobní hodnotu, nýbrž i určitou proslulost obce. Krátce řečeno - zvýrazňuje se tím jejich dobrá pověst navenek.

\section{Závěr}

Provázanost svébytných domén historické sociologie i vlastní historiografie je ve zde uvedených bádáních zřejmá. Můžeme tak poměrně dobře reflektovat specifickou technickou oblast, její pragmatiku i znakovou funkci. Protínají se přitom různé aspekty mobility, včetně novodobé motorizace.

Metodologicky a metodicky se $\mathrm{k}$ této oblasti studia nabízí mimo jiné závěry francouzského sociologa Pierra Bourdieu [1998]. Podle něj je nutné vycházet z určitého jednotícího principu, jeho terminologií řečeno „habitu“, který vytváří identifikovatelný životní styl a v němž se sjednocuje volba statků i praktických činností. Právě habitus představuje systém generující jednání, a může tím pádem poskytnout východisko pro zkoumání určitého sociálního pole, $\mathrm{v}$ našem př́padě konkrétních lokálních komunit. Na váhu ovšem v různé míře padají i mnohé limity, dané z hlediska našeho bádání především lokálně, na druhé straně nelze opominout ani záliby, vkus apod.

Mobilita představuje ve svém souhrnu proces akcelerace, zde konkrétně zrychlení pohybu na venkově. Zahrnuje i určitou scéničnost v př́rodním prostředí. Mobilita se v námi představeném mikroregionu skutečně dosti prudce změnila s nástupem motorizace, zejména v souvislosti s automobily a motocykly. Ještě předtím, tj. na počátku 20. století, už velocipéd zrychlil pohyb oproti tradičnímu pěšímu přesunu. Nedá se nakonec říci, že by venkov v (auto)mobilitě výrazně zaostával oproti městským sídlům. V dalším bádání proto půjde o kvalitativní a kvantitativní vyjádření této problematiky, jakož i o její časové zakotvení.

\section{Literatura}

Barthes, Roland [2004]. Mytologie. Praha: Dokořán.

Bourdieu, Pierre [1998]. Teorie jednání. Praha: Karolinum.

Haukanes, Haldis [2004]. Velká dramata - obyčejné životy. Postkomunistické zkušenosti českého venkova. Praha: Sociologické nakladatelství.

Jakubec, Ivan [2018]. Společenská dimenze českého motorismu. Historická sociologie (2): 127-133. 
Kottak, Conrad Philip [2000]. Anthropology. The Exploration of Human Diversity. Boston: McGraw Hill. Malypetr, Marcel [2008]. Skútr Čezeta. Renovace, údržba, opravy, technika. Praha: Grada.

Šalanda, Bohuslav [2008]. Česká vesnice Široký Důl. Kolín: Nezávislé centrum pro studium politiky. Tempír, Zdeněk, a kol. [1987]. Historické traktory v Československu. Praha: Zemědělské muzeum. Toffler, Alvin - Tofflerová, Heidi [2001]. Nová civilizace. Třetí vlna a její dưsledky. Praha: Dokořán. Tuček, Jan [2009]. Auta východního bloku. Praha: Grada.

Urry, John [2007]. Mobilities. Cambridge, UK: Polity.

Wohlmuth, Jiří [2015]. Jawa 50 Pionýr. Historie, vývoj technika, sport. Praha: Grada.

Bohuslav Šalanda působí na Pracovišti historické sociologie Fakulty humanitních studií Univerzity Karlovy. Odborně se zabývá sociologickými a etnologickými výzkumy lokálních společenství, v poslední době zaměřnenými na studium (auto)mobility. 